\title{
A Few Words on the "Cross-Cutting Issue"-The Relationship between a BBNJ Convention and Existing, Relevant Instruments and Frameworks and Relevant Global, Regional and Sectoral Bodies
}

\author{
Ted L. McDorman
}

\begin{abstract}
Since the 198 os the architecture of international ocean governance has rested on the UN Convention on the Law of the Sea (Los Convention) and a large number of the regional and global sectoral treaties most of which were contemplated in the Los Convention. One of the central challenges in the negotiation of a BBNJ Convention is the "architectural fit" of а ввNJ Convention with the existing treaty-based law of the sea governance framework.

The primary focus of this presentation is on several selected legal relationship issues: the relationship of а ввNJ Convention with the LOs Convention, which has several aspects including the activities by a coastal State in the exercise of its jurisdiction over the resources in the continental shelf beyond 20onm; and the relationships issues that may/will arise from area-based management measures and existing treaty-based governance bodies such as regional fisheries management organizations (RFMOs) and the various Iмо Conventions. Here the mantra is that а в вNJ Convention will not "undermine" existing instruments and frameworks.
\end{abstract}

\section{Keywords}

marine biological diversity - areas beyond national jurisdiction - treaty negotiations United Nations Convention on the Law of the Sea - area-based management - regional fisheries management organizations - international treaties 
In 2004, pursuant to the annual United Nations General Assembly Oceans Resolution, the Ad Hoc Open-ended Informal Working Group to Study Issues relating to the Conservation and Sustainable Use of Marine Biological Diversity Beyond Areas of National Jurisdiction was created. ${ }^{1}$ Its first meeting came in 2006. Thus began the process that led first to the July 2015 UN General Assembly Resolution directing States to "develop an international legally binding instrument ... on the conservation and sustainable use of marine biological diversity of areas beyond national jurisdiction"2 referred to herein as the вв NJ Convention and then to the 24 December 2017 General Assembly Resolution deciding that an intergovernmental conference be convened to complete a вв NJ Convention. ${ }^{3}$ The first session of the intergovernmental conference took place in September 2018, ${ }^{4}$ the second in March-April $2019^{5}$ and the third is scheduled for August 2019 .

The first report of the Ad Hoc Open-ended Informal Working Group in 2006 noted:

The cross-cutting nature of marine biological diversity, as well as the existence of numerous, and often competing, legal frameworks and bodies,

* This paper was prepared and presented prior to the release of the "Draft text on an Agreement under the United Nations Convention on the Law of the Sea on the Conservation and Sustainable use of Marine Biological Diversity of Areas Beyond National Jurisdiction," "Note by the President," A/CONF.232/2019/6, 17 May 2019 and prior to the Third session (August 2019) of the Intergovernmental Conference on an International Legally Binding Instrument Under the United Nations Convention on the Law of the Sea on the Conservation and Sustainable Use of Marine Biological Diversity of Areas Beyond National Jurisdiction. However, some reference is made in the paper to the May 2019 Draft Convention.

1 UN General Assembly Resolution, "Oceans and the Law of the Sea," A/REs/59/24, 4 February 2005, (adopted 17 November 2014), para. 73. [THE CORRECT YEAR IS 2004.]

2 UN General Assembly Resolution, "Development of an Internationally Legally Binding Instrument under the United Nations Convention on the Law of the Sea on the Conservation and Sustainable Use of Marine Biological Diversity of Areas Beyond National Jurisdiction," A/ RES/69/292, 6 July 2015, (adopted 19 June 2015), para. 1.

3 UN General Assembly Resolution, "International Legally Binding Instrument under the United Nations Convention on the Law of the Sea on the Conservation and Sustainable Use of Marine Biological Diversity of Areas Beyond National Jurisdiction," A/Res/72/249, 19 January 2018, (adopted 24 December 2017).

4 See: "Statement by the President of the Conference at the Closing of the First Session," A/ CONF.232/2018/7, 20 September 2018.

5 See: "Statement by the President of the Conference at the Closing of the Second Session," A/ CONF.232/2019/5, 18 April 2019. 
lead numerous delegations to stress the importance of improving coordination and cooperation among international organizations as well as among sectors and regimes.... ${ }^{6}$

It was also noted that: "most delegations re-emphasized that the Convention (on the Law of the Sea) provided the legal framework for the conservation and sustainable use of marine biological diversity beyond areas of national jurisdiction."7

The point of this walk down memory lane is simply to point out, that, as the architecture of international ocean governance rests on the UN Convention on the Law of the Sea (Los Convention) ${ }^{8}$ and a large number of the regional and global sectoral treaties, many of which were contemplated in the Los Convention, one of the central challenges in the negotiation of а вBNJ Convention has always been the "architectural fit" of a BBNJ Convention within the existing treaty-based law of the sea governance framework.

It is generally accepted that a BвNJ Convention will be an implementing agreement of the Los Convention in the same legal manner as the 1995 Fish Stocks Agreement ${ }^{9}$ and the 1994 Agreement relating to the Implementation of Part XI of the LOs Convention. ${ }^{10}$

It is also generally accepted, as stated in both the 2015 General Assembly Resolution"11 and the 2017 Resolution, ${ }^{12}$ that a BBNJ Convention "should not undermine existing relevant legal instruments and frameworks and relevant global, regional, and sectoral bodies."

While these two generally accepted understandings deal with different subjects they are often grouped together as being a so-called "cross-cutting element" - the relationship between a вB NJ Convention and the "United Nations Convention on the Law of the Sea and other instruments and frameworks and relevant global, regional and sectoral bodies."

$6 \quad$ "Report of the Ad Hoc Open-ended Informal Working Group to Study the Issues relating to the Conservation and Sustainable Use of Marine Biological Diversity beyond Areas of National Jurisdiction," A/61/65, 20 March 2006, para. 53 .

$7 \quad$ Ibid., para. 22.

8 United Nations Convention on the Law of the Sea, 1833 U.N.T.S. 397.

9 Agreement for the Implementation of the Provisions of the United Nations Convention on the Law of the Sea of 10 December 1982 relating to the Conservation and Management of Straddling Fish Stocks and Highly Migratory Fish Stocks, 2167 U.N.T.S. 3.

10 Agreement relating to the Implementation of Part XI of the United Nations Convention on the Law of the Sea of 10 December 1982, 1836 U.N.T.S. 3 .

11 Resolution, 69/292, supra note 2, para. 3.

12 Resolution 72/249, supra note 3, para 7. 
The modest intention of this contribution is to say a few words respecting the "cross-cutting" issue of the "relationship of the Los Convention on the Law of the Sea and other instruments and frameworks and relevant global, regional and sectoral bodies" with a potential ввNJ Convention.

This approach is primarily that of a technical international lawyer seeking to understand how various treaties may be affected or interact with a potential BBNJ Convention.

\section{Background on Relationships between International Treaties ${ }^{13}$}

International law and practice provide little assistance respecting the abstract question of the relationship between treaties with similar content, mandates or goals.

The Vienna Convention on the Law of Treaties ${ }^{14}$ provides an answer to the narrow question of precedence in the situation where treaty provisions can be said to conflict. First, Article 30 directs that where there is a conflict in or between two treaties and the parties to the treaties are the same, the more recently concluded convention prevails..$^{15}$ Second, where there is a conflict in two treaties and one State is a party to both and another State is a party only to one of the treaties, then it is the treaty that is common to both States that prevails. ${ }^{16}$ The above provisions of the Vienna Convention are residual rules that only come into play where the treaties in collision are silent. ${ }^{17}$

Treaties often contain relationship clauses, sometimes called conflict or savings clauses, which seek to provide how treaties and/or provisions with similar subject matter interrelate. Such clauses:

13 This section is drawn, with modification, from T. L. McDorman, "A Note on the Potential Conflicting Treaty Rights and Obligations between the IMO's Polar Code and Article 234 of the Law of the Sea Convention," in Suzanne Lalonde and T.L. McDorman, eds., International Law and Politics of the Arctic Ocean (Boston/Leiden: Brill/Nijhoff, 2015), pp.146-148.

14 Vienna Convention on the Law of Treaties, 1155 U.N.T.S. 331.

15 Ibid. Articles $30(3)$ and (4)(a).

16 Ibid., Article 3o(4). More generally on these two provisions in the Vienna Convention, see: Mark E. Villiger, Commentary on the 1969 Vienna Convention on the Law of Treaties (Leiden: Martinus Nijhoff, 2009), at pp. 395-411 and Jan Klabbers, "Beyond the Vienna Convention: Conflicting Treaty Provisions" in Enzo Cannizzaro, ed., The Law of Treaties: Beyond the Vienna Convention (Oxford: Oxford University Press, 2011), pp. 192-205.

17 See Ian Sinclair, The Vienna Convention on the Law of Treaties, 2nd ed. (Manchester: Manchester University Press, 1984), at p. 97. 
are meant to avoid that treaties covering similar or at least partially overlapping subject matters contradict each other. Therefore, their primary objective is the safeguarding of a general coherence of international law..$^{18}$

Obviously, such a clause is of limited effect where there is only one of the conflicting treaties common to both States. Article 30(2) of the Vienna Convention provides that: When a treaty specifies that it is subject to, or that it is not to be considered as incompatible with, an earlier or later treaty, the provision of that treaty shall prevail.

As suggested by these provisions, a direct legal question regarding the relationship of treaties only arises where there is a conflict of obligations or rights in two treaties. It is understood that treaties are to be read so as to be in harmony and, to the extent possible, to avoid conflicts. What constitutes a conflict between treaties is not precisely clear..$^{19}$ At its narrowest, a conflict exists between treaty provisions when "one obligation cannot be fulfilled without necessarily violating the other."20 This view has been challenged as being "too restrictive," since "States are not only concerned when a State cannot abide by two treaties but also where one treaty frustrates the goals of another treaty."21 There are other ways of understanding when treaties are in conflict. ${ }^{22}$

\section{The Relationship between a в вNJ Convention and the LOS Convention}

As noted above, the 2015 and 2017 General Assembly Resolutions direct that a BBNJ Convention is to be "under" the Los Convention, ${ }^{23}$ which means that а ввNJ Convention is to be an "implementation" of the relevant parts of the 1982 LOS Convention in the same manner as the 1995 Fish Stocks Agreement ${ }^{24}$

18 Rüdiger Wolfrum and Nele Matz, Conflicts in International Environmental Law (Berlin: Springer, 2003), at p. 121.

19 Christopher J. Borgen, "Treaty Conflicts and Normative Fragmentation" in Duncan B. Hollis, ed., The Oxford Guide to Treaties (Oxford: Oxford University Press, 2012), at p. 455, notes that "there is no generally accepted definition of what constitutes a conflict." Wolfrum and Matz, supra note 18, at p. 6 and Seyed Ali Sadat-Akhavi, Methods of Resolving Conflicts between Treaties (Leiden: Martinus Nijhoff, 2003), at p. 5 .

21 Borgen, supra note 19, at p. 455.

22 See: Wolfrum and Matz, supra note 18, at pp. 6-12.

23 Resolution, 69/29, supra note 2, para. 1 and Resolution 72/249, supra note 3, para. 1.

24 Fish Stocks Agreement, supra note 9. 
and the 1994 Agreement relating to the Implementation of Part XI of the LOS Convention. ${ }^{25}$

Article 4 of the Fish Stocks Agreement provides:

Nothing in this Agreement shall prejudice the rights, jurisdiction and duties of States under the Convention. This Agreement shall be interpreted and applied in the context of and in a manner consistent with the Convention.

Not surprisingly, the above wording was copied in the Report of the Preparatory Committee elements of a BBNJ Convention ${ }^{26}$ and in the Draft Text of a BB NJ Agreement (May 2019), prepared by the President of the ввNJ Conference. ${ }^{27}$

The clear intention of the wording is that the rights, jurisdiction and duties set out in the LOs Convention are to be unaffected by the contents of a BвNJ Convention which, in the vernacular of the Vienna Convention on the Law of Treaties, means that as between States a party to both the Los Convention and а ввNJ Convention, should a conflict of rights, duties or responsibilities arise, the Los Convention prevails over a BвNJ Convention.

For practical purposes, more important may be the second sentence: "The Agreement shall be interpreted and applied in the context of and in a manner consistent with the Convention." This directs States, courts and tribunals that are involved in the interpretation or application of a вBNJ Convention, to interpret and apply a вBNJ Convention "in a manner consistent with" the Los Convention. Essentially, in this context, the interpretation of wording provision can be said to add an extra element, one that is binding on the State parties and courts and tribunals that have jurisdiction to resolve disputes regarding the interpretation or application of a BBNJ Convention.

If the provisions above are replicated as is or as in substance in a BBNJ Convention, such a provision can be understood as a non-interference provision or, perhaps more properly, as a coordination provision, as the wording would

25 Agreement relating to the Implementation of Part XI, supra note 10.

26 UN General Assembly, "Report of the Preparatory Committee established under General Assembly Resolution 69/292: Development of an Internationally Legally Binding Instrument under the United Nations Convention on the Law of the Sea on the Conservation and Sustainable Use of Marine Biological Diversity of Areas Beyond National Jurisdiction," A/AC.287/2017/PC.4/2, 31 July 2017, at p. 8.

27 "Draft Text on an Agreement under the United Nations Convention on the Law of the Sea on the Conservation and Sustainable use of Marine Biological Diversity of Areas Beyond National Jurisdiction," "Note by the President," A/CONF.232/2019/6, 17 May 2019, Article 4(1). 
act as a limitation on both the geographic and material scope and application of a BBNJ Convention.

One area where this can be seen as being of particular sensitivity for many States is regarding the rights and duties of a coastal State respecting the mineral resources (and sedentary species) in the continental shelf beyond $200 \mathrm{M}$ over which the coastal State has exclusive rights. ${ }^{28}$ While the conservation and sustainable use of marine biological diversity in the water column above the continental shelf of a State beyond $200 \mathrm{M}$ is expected to be within the geographic and material scope of a ввNJ Convention, the Report of the Preparatory Committee ${ }^{29}$ and the President of the BBNJ Conference May 2019 Draft Text of a B BNJ Convention indicate that the rights and jurisdiction of a coastal State regarding the shelf area beyond $200 \mathrm{M}$ "shall be respected." 30

A relationship clause constructed consistent with that envisioned above reinforces and protects the rights and jurisdiction of the coastal State to conduct activities on the shelf irrespective of the content of а в вNJ Convention. Having said this, a legally stronger and broader provision would be: "Nothing in this Convention shall interfere directly or indirectly with the rights and jurisdiction of a coastal State regarding the shelf area beyond 200 nautical miles."

Not explicitly noted in the Report of the Preparatory Committee or in the President of the BBNJ Conference May 2019 Draft Text of a BBNJ Convention is the relationship that is to exist between the 1995 Fish Stocks Agreement and the 1994 Part XI Agreement and a BBNJ Convention. Both of these Agreements deal specifically and primarily with resources located within areas beyond national jurisdiction. In the case of the Part XI Agreement it is the mineral resources that are subject to the "Common Heritage of Mankind." ${ }^{31}$ In the case of the 1995 Fish Stock Agreement, the resources are fisheries subject to the freedom to fish with the 1995 Agreement having led to a proliferation of regional fisheries management organizations (RFMOs) which manage the stocks of selected fisheries on the high seas.

None of the above deals with a central dividing point in the ввNJ discussions, (again well-articulated in the 2006 First ad hoc Working Group Report): Are marine genetic resources subject to the Los Convention freedom of the high seas regime with open access and freedom of marine scientific research? Or, are marine genetic resources covered by the Common Heritage wording of the

28 LOS Convention, supra note 8, Part vi.

29 "Report of the Preparatory Committee," supra note 26, at p. 8.

30 BвnJ Conference President, May 2019, Draft Text, supra note 27, Article 4(2).

31 See: Los Convention, supra note 8, Article 1, Part XI and in particular Article 136. 
Los Convention such that there is no open access or freedom of the high seas or marine scientific research respecting marine genetic resources?

[A] number of delegations stated that, in accordance with their understanding of the principle of the common heritage of mankind, access to genetic resources in the deep seabed beyond areas of national jurisdiction should be, in principle, like the mineral resources in the Area, subject to the sharing of benefits based on consideration of equity. ${ }^{32}$

Referring to the legal status of genetic resources, a view was expressed that any measures taken in areas beyond national jurisdiction must be consistent with international law, including freedom of navigation and of marine scientific research. Some delegations stated that the resources were covered by the regime of the high seas, under part viI of the Convention. They argued that there was no legal gap with respect to living resources in the areas beyond national jurisdiction and that freedoms of the high seas were applicable to activities relating to marine genetic resources. ${ }^{33}$ Regional and Sectoral Bodies"

\section{Introduction}

As noted above, "the Relationship between a BвNJ Convention and Existing Relevant Instruments and Frameworks and Relevant Global, Regional and Sectoral Bodies" is a "cross-cutting" issue in the BBNJ Convention negotiations.

As part of the Preparatory Committee process two lists of treaties that either specifically have as their geographical scope areas beyond national jurisdiction or that deal with issues relating to the conservation and sustainable use of marine biodiversity of areas beyond national jurisdiction were created. The lists contain over 60 instruments. ${ }^{34}$

There are two sets of sectoral treaties that obviously may be impacted directly or indirectly by a $\mathrm{BBNJ}$ Convention as regards area-based management

32 "Report of the Ad Hoc Open-ended Informal Working Group, March 2oo6, supra note 6, para. 29.

33 Ibid., at para. 3 o.

34 U.N. Division of Oceans and the Law of the Sea (DOALOS), "Indicative List of Regional Treaties," (undated), on the DoALos website, at www.un.org/depts/los/. 
measures. These are the treaties that create the RFMO s and the treaties adopted through the International Maritime Organization (IMO). The RFMO s have as their geographic scope areas of the high seas and focus on the sustainable management of the various fish stocks under their mandates and are not mandated to take into account or deal with the larger scope of the conservation and sustainable use of marine biological diversity beyond national jurisdiction. The Iм0 Conventions primarily deal with vessel standards that apply wherever a commercial vessel is operating, including on the high seas.

As a generality, the relative clarity of the relationship between the Los Convention and the ввNJ Convention is missing as regards the relationship between a BBNJ Convention and the "existing relevant legal instruments and frameworks and relevant global, regional and sectoral bodies."

\section{2 "Undermine"}

As already noted, the 2015 and 2017 General Assembly Resolutions state that a вв NJ Convention "should not undermine existing relevant legal instruments and frameworks and relevant global, regional, and sectoral bodies." As Catherine Blanchard has noted: "the wording of the not undermining clause comes from recommendations of the Working Group, and the drafting history of these recommendations is very indicative of the political nature that surrounded the adoption of the clause." 35

The Report of the Preparatory Committee indicated that a ввNJ Convention "... should be interpreted and applied in a manner which would not undermine" existing legal instruments and frameworks. ${ }^{36}$ This wording may be seen as recognizing the legal primacy of the existing structures (for example, RFMOS) that deal directly or indirectly with the conservation and sustainable use of marine biological diversity beyond national jurisdiction. Other wording in the Report of the Preparatory Committee dealing specifically with areabased management tools (including marine protected areas) referred to "the importance of enhanced cooperation and coordination between legal instruments ... without prejudice to their respective mandates." ${ }^{37}$

35 Catherine Blanchard, “Could 'Not Undermining' Undermine the BBNJ Process: Possible Interpretations of the Relationship between the 'Not Undermining' Clause and the Upcoming Legally Binding Instrument on the Conservation and Sustainable Use of Marine Biodiversity Beyond National Jurisdiction," paper at the Law of the Sea Interest Group of the European Society of International Law, in Naples, September 2017.

36 "Report of the Preparatory Committee," supra note 26, at p. 9.

37 Ibid. at p. 11. 
The above is captured in Article 4(3) of the President of the BBNJ Conference May 2019 Draft Text of a BBNJ Convention:

This Agreement shall be interpreted and applied in a manner that [respects the competences of and] does not undermine [existing] relevant legal instruments and frameworks and relevant global, regional and sectoral bodies and that promotes coherence and coordination with those instruments, frameworks and bodies, provided that they are supportive of and do not run counter to the objectives of the Convention and this Agreement. $^{38}$

An expansive understanding of the term "undermine" could act as a significant limitation on the scope and application of a BBNJ Convention but would avoid or prevent undue interference by а ввNJ Convention with the existing global, regional and sectoral bodies. The opposite result occurs if "undermine" is understood in a narrow sense.

Article 31(1) of the Vienna Convention directs one to interpret treaty text by looking at "ordinary meaning." 39 The Oxford English Dictionary indicates that to undermine something is to make something weaker or less effective. This suggests a narrow approach such that it gives a BBNJ Convention opportunities to add to "existing relevant legal instruments and frameworks and relevant global, regional, and sectoral bodies." Others have undertaken more detailed studies of interpreting the "undermine" wording. ${ }^{40}$

\section{$3 \quad$ Legal Relationship}

The legal relationship between а ввNJ Convention and those "Existing Relevant Instruments and Frameworks and Relevant Global, Regional and Sectoral Bodies" that are treaties will depend primarily on the inclusion and wording of legal obligations on States in a BBNJ Convention. As pointed out above, only where there is a conflict of treaty rights and obligations is there a question of the legal relationship.

38 в BNJ Conference President, May 2019, Draft Text, supra note 27, Article 4(3).

39 Vienna Convention on the Law of Treaties, supra note 14, Article 31(1).

40 See: Blanchard, supra note 35; Zoe Scallion, "The Art of 'not Undermining': Possibilities within Existing Architecture to Improve Environmental Protection in Areas Beyond National Jurisdiction," (2018), 75 ICES Journal of Marine Science 405-416; A. Friedman, "Beyond 'Not Undermining': Possibilities for Global Cooperation to Improve Environmental Protection in Areas Beyond National Jurisdiction: Comment," (2019), 76 ICES Journal of Marine Science 452-456; and Vito De Lucia, "Reflecting on the Meaning of 'Not Undermining' Ahead of IGC-2," JCLOs Blog, 23 March 2019. 
At least concerning area-based management measures, there does appear that there will be direct obligations on States party to a BBNJ Convention that can be said to conflict with, for example, measures adopted by RFMO sor with any of the obligations in the IMO Conventions. It is apparent that most of the output of a BBNJ Convention on area-based management measures will be accomplished through a Conference of the Parties (COP) with the BBNJ Convention wording providing guidance, direction and principles.

COPs in multilateral environmental agreements (MEAs) do not have the authority to adopt legally-binding measures or direct other bodies to adopt measures. ${ }^{41}$ This is the case as regards the much-admired Convention on Biological Diversity, ${ }^{42}$ for example, where the COP adopts "decisions" but such decisions are not legally binding on the State Parties to the Св D. That this legal nicety is often over-looked by commentators and СвD participants alike does not change the legal situation.

The result of the above regarding the legal-relationship question is that the "Existing Relevant Instruments and Frameworks and Relevant Global, Regional and Sectoral Bodies" that are treaty-based and contain treaty-based obligations and rights (such as under RFMOs and the IMO Conventions) are treaty rights and obligations that will be legally unaffected by a BBNJ Convention, in particular, unaffected by decisions that may emanate from a вBNJ СOP.

\section{Conclusion}

After 13+ years of heavy fog, the outlines of a possible BBNJ Convention are beginning to emerge. It is the case, however, that with respect to the "deal-breaker issues" a dense fog remains concerning access to marine genetic resources.

The wording that а ввNJ Convention is not to "undermine existing relevant instruments and frameworks and relevant global, regional and sectoral bodies," has been acceptably ambiguous (foggy) for high-level discussion and agreement. It is highly likely that "not to undermine" will continue to be

41 See:Annecoos Wiersema, "The New International Law-Makers? Conferences of the Parties to Multilateral Environmental Agreements" (2009), 31 Michigan Journal of International Law 231, at pp. 286-287 whose conclusion summarizes that: "COP activity does not create new stand-alone law. ... Using conventional approaches for determining the sources of international law ... COP activity would rarely be classified as hard international law." The author argues that such conventional approaches "fail to capture this activity's tight relationship with the underlying treaty obligations of the parties."

Convention on Biological Diversity, 176o U.N.T.S. 79 . 
acceptably ambiguous and will appear in a BвNJ Convention (assuming one is completed).

Based on precedent, a BBNJ COP will not have the scope or authority to adopt measures that are legally binding on States and, therefore, will not supersede directly or affect indirectly legal obligations or rights that arise from regional or global sectoral treaties.

Pragmatically, one hopes that the BвNJ Convention will enhance coordination of global and regional governance of biodiversity beyond national jurisdiction while avoiding interference with intergovernmental regional and sectoral bodies. 